University of Nebraska - Lincoln

DigitalCommons@University of Nebraska - Lincoln

USDA National Wildlife Research Center - Staff Publications
U.S. Department of Agriculture: Animal and Plant Health Inspection Service

2011

\title{
Testing the Terrain Hypothesis: Canada Geese See Their World Laterally and Obliquely
}

\author{
Esteban Fernández-Juricic \\ Purdue University \\ Bret A. Moore \\ Purdue University \\ Megan Doppler \\ Purdue University \\ Joseph Freeman \\ Purdue University \\ Bradley F. Blackwelll \\ USDA/APHIS/WS National Widldlife Research Center, bradley.f.blackwell@aphis.usda.gov \\ See next page for additional authors
}

Follow this and additional works at: https://digitalcommons.unl.edu/icwdm_usdanwrc

Part of the Life Sciences Commons

Fernández-Juricic, Esteban; Moore, Bret A.; Doppler, Megan; Freeman, Joseph; Blackwelll, Bradley F.; Lima, Steven L.; and DeVault, Travis L., "Testing the Terrain Hypothesis: Canada Geese See Their World Laterally and Obliquely" (2011). USDA National Wildlife Research Center - Staff Publications. 1291.

https://digitalcommons.unl.edu/icwdm_usdanwrc/1291

This Article is brought to you for free and open access by the U.S. Department of Agriculture: Animal and Plant Health Inspection Service at DigitalCommons@University of Nebraska - Lincoln. It has been accepted for inclusion in USDA National Wildlife Research Center - Staff Publications by an authorized administrator of DigitalCommons@University of Nebraska - Lincoln. 


\section{Authors}

Esteban Fernández-Juricic, Bret A. Moore, Megan Doppler, Joseph Freeman, Bradley F. Blackwelll, Steven L. Lima, and Travis L. DeVault 


\title{
Testing the Terrain Hypothesis: Canada Geese See Their World Laterally and Obliquely
}

\author{
Esteban Fernández-Juricic ${ }^{a} \quad$ Bret A. Moore $^{a} \quad$ Megan Doppler $^{a} \quad$ Joseph Freeman $^{\mathrm{a}}$ \\ Bradley F. Blackwell ${ }^{b}$ Steven L. Limac Travis L. DeVault ${ }^{\mathrm{b}}$ \\ ${ }^{a}$ Department of Biological Sciences, Purdue University, West Lafayette, Ind., ${ }^{b}$ Ohio Field Station, National Wildlife \\ Research Center, Wildlife Services, Animal and Plant Health Inspection Service, United States Department of \\ Agriculture, Sandusky, Ohio, and ' Department of Biology, Indiana State University, Terre Haute, Ind., USA
}

\section{Key Words}

Birds - Canada goose $\cdot$ Ganglion cells $\cdot$ Retinal topography Terrain hypothesis $\cdot$ Vigilance $\cdot$ Visual fields

\begin{abstract}
The distribution of ganglion cells in the retina determines the specific regions of the visual field with high visual acuity, and thus reflects the perception of a species' visual environment. The terrain hypothesis proposes that animals living in open areas should have a horizontal visual streak across the retina with high ganglion cell density to increase visual acuity along the horizon. We tested this hypothesis in Canada geese (Branta canadensis) by assessing retinal topography, visual field configuration, and scanning behavior. We found that geese have an oblique rather than a horizontal visual streak across the retina: from a dorsal-nasal to a ventral-temporal position. Geese showed narrow blind areas, which increased the range of their lateral vision, and a relatively large degree of eye movement. Canada geese have relatively wide binocular fields and can see their bill tips. Goose head movement rates were low compared to species with a single fovea, and head movement rates increased in visually obstructed habitats. Canada geese have high acuity across their retina, which would allow them to simultaneously scan
\end{abstract}

the ground and the sky when the head is up and parallel to the ground, as well as align the visual streak with the horizon when the head is tilted downwards. Their visual streak, along with their large eye size, may reduce the need for large amplitude head movements during vigilance bouts in visually unobstructed habitats. Overall, the visual system of geese combines features related to the detection of predators/conspecifics in open areas (visual streak, large lateral field, reduced head movements) as well as visual specializations that would allow for monitoring both the ground and sky (oblique streak) and for extracting and handling of food items (wide binocular fields, visualization of the bill tip).

Copyright $\odot 2011$ S. Karger AG, Basel

\section{Introduction}

The retina is a multilayered tissue that filters visual information that organisms use to interact with their environment. Visual phototransduction (i.e., conversion of light into electrical signals) takes place in the rods and cones, and information is then channeled into the brain through the retinal ganglion cells whose axons form the optic nerve [McIlwain, 1996]. Retinal ganglion cells can be thought of as bottlenecks of the information available

\section{KARGER}

Fax +41613061234 E-Mail karger@karger.ch www.karger.com

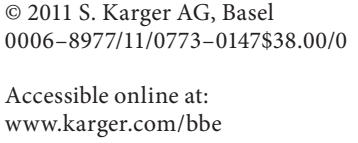

Esteban Fernández-Juricic

Department of Biological Sciences, Purdue University

Lilly Hall G-302, 915 W. State Street

West Lafayette, IN 47907 (USA)

Tel. +1 765494 6044, E-Mail efernan@purdue.edu 
in the visual space [Collin, 1999]. Variations in the density of retinal ganglion cells across the retina have been associated with the visual characteristics of an organism's habitat [Hughes, 1977; Collin, 1999]. In particular, areas in the retina with a high density of retinal ganglion cells, known as retinal specializations, increase visual resolution in the area of the visual field to which they project [Meyer, 1977]. Areas with a high concentration of specific types of retinal ganglion cells are also considered retinal specializations, such as the giant alpha-type ganglion cells that have been involved in movement detection [Hayes et al., 1991].

There are different types of retinal specializations associated with higher visual resolution [Pumphrey, 1948; Meyer, 1977]. For example, an area is a concentric increase in the density of retinal neurons that in many cases is associated with a central pit-like invagination of the retinal tissue termed fovea. The area and the fovea vary in number and position across the retina in different species [Pumphrey, 1948; Meyer, 1977; Collin, 1999]. For instance, pigeons have a central fovea projecting into the lateral visual field involved in the detection of distant objects, and a dorsal temporal area projecting into the binocular field involved in the detection of food items [e.g., Querubin et al., 2009]. Another type of retinal specialization is the visual streak: a ribbon-like area with high density of retinal neurons that runs across the retina [Chievitz, 1891; Slonaker, 1897; Pumphrey, 1948; Hughes, 1977; Meyer, 1977]. The presence of a visual streak has been associated with habitat-type, and antipredator and orientation behaviors [Johnson, 1901; Vincent, 1912; Pumphrey, 1948; Luck, 1965; Hughes, 1977].

The terrain hypothesis proposes that organisms inhabiting open habitats (e.g., grassland, desert, ocean floor, coral reef, etc.) should have a visual streak to enhance visual resolution along the horizon [Hughes, 1975, 1977]. This visual streak is expected to provide constant visual resolution along the extended flat terrain, as well as increased sensitivity to movement for the detection of prey and predators [Hughes, 1977]. Several species of birds inhabiting open habitats have been found to possess a visual streak [e.g., burrowing owl Athene cunicularia, Bravo and Pettigrew, 1981; ostrich Struthio camelus, Boire et al., 2001; Manx shearwater Puffinus puffinus, sooty albatross Phoebetria fusca, soft-plumaged petrel Pterodroma mollis, Hayes et al., 1991]. The visual streak is not unique to birds, as it is found in other taxa [e.g., smallspotted dogfish Scyliorhinus canicula, Bozzano and Collin, 2000; Australian frogfish Halophryne diemensis, Collin and Pettigrew, 1988; spotted hyena Crocuta crocuta,
Calderone et al., 2003]. Species with a visual streak have been proposed to have wide panoramic vision [Johnson, 1901; Hughes, 1977], and thus wide lateral visual fields and narrow blind areas which increase visual coverage. Having a horizontal visual streak with high visual resolution across the retina reduces the need to sample visual information through eye movements [Collin, 1999].

The framework of the terrain hypothesis can also be expanded into vigilance behavior (e.g., monitoring the visual space), which in some taxa (e.g., birds) is defined in part by head movements. Moving the head allows birds to shift their visual fields to enhance visual coverage, estimate distances to or from objects, and investigate objects with retinal regions of high acuity [Dunlap and Mowrer, 1930; Dawkins, 2002; Kral, 2003]. A horizontal streak would reduce the need to scan the visual space and allow the exploration of objects without requiring wide head movements due to the large area of high visual resolution across the retina. However, in areas with high levels of visual obstruction (e.g., closed habitats), animals with a visual streak may actually increase head movements to compensate for the loss of visual coverage. Although the visual streak has been well-characterized morphologically [Hughes, 1977], there is relatively less information on the association between the presence of a streak and vigilance behavior. This information is necessary to better understand the relationship between retinal morphology and behavior in visually guided organisms.

The goal of this study was to test the predictions of the terrain hypothesis on the Canada goose (Branta canadensis), taking into account the topography of the retinal ganglion cell layer, the configuration of the visual fields, the degree of eye movement, and the patterns of head movement in micro-habitats with different degrees of visual obstruction (e.g., tree cover). Canada geese occupy a wide variety of habitats (prairie, parkland, plains, meadows, semiopen forests, etc.), but they prefer to nest in open areas close to water sources [Mowbray et al., 2002]. Canada geese feed on above-ground plant matter (grasses, crops, berries, etc.), but will also consume bulbs and submerged vegetation [Mowbray et al., 2002]. This species is gregarious during the nonbreeding season, but it becomes highly territorial when breeding [Mowbray et al., 2002]. Both males and females actively defend their nests [Sjöberg, 1994] and increase their vigilance behavior when in the company of their precocial offspring [Seddon and Nudds, 1994; Caithamer et al., 1996; Fowler and Ely, 1997]. There are many accounts of predation on adult geese by both ground (e.g., coyotes Canis latrans, 
gray wolves Canis lupus) and aerial (snowy owls Nyctea scandiaca, golden eagles Aquila chrysaetos, bald eagles Haliaeetus leucocephalus) predators [Mowbray et al., 2002]. In general, the time budgets and use of water bodies as safe areas by Canada geese appear substantially affected by the levels of predation risk [Raveling et al., 1972].

\section{Methods}

The Canada geese we used in this study were captured by corralling flightless individuals during molt into a netted pen with cooperation with the US Department of Agriculture, Animal and Plant Health Inspection Service (USDA-APHIS) (Federal Permit MB019065-1, State Permit 11-299). All animal handling and experimental procedures were approved by the Purdue Animal Care and Use Committee (PACUC, protocol No. 09-018). We used 11 Canada geese from the Branta canadensis maxima subspecies, which were housed in a room kept on a 14-hour light cycle at approximately $23^{\circ} \mathrm{C}$ with food (whole kernel corn) and water provided ad libitum. We measured different components of the visual field configuration on the 11 individuals, of which 7 were used for retina extraction.

\section{Retinal Topography}

We euthanized the geese following PACUC recommendations, and promptly removed the eyes. We measured axial length (anterior portion of the cornea to the most posterior portion of the back of the eye), corneal diameter (inner diameter of the sclerotic ossicles), and transverse diameter (outer diameter of the eyeball from side to side) to an accuracy of $0.01 \mathrm{~mm}$ using digital calipers. We hemisected the eye at the ora serrata using a razor blade and removed all vitreous humor using forceps and spring scissors. We extracted the retina by gently separating the choroidal layer from the sclera and cutting the optic nerve with a scalpel. All choroid and the pigmented epithelium were removed.

We placed the retina in a $4 \%$ paraformaldehyde in phosphatebuffered saline solution ( $\mathrm{pH}$ 7.3) for $24 \mathrm{~h}$. Afterwards, we washed the retina in phosphate-buffered saline and flattened it onto a gelatinized slide [Stone, 1981]. We made radial cuts to flatten the retina on the slide, and then removed the pecten. We fixed the retina to the slide by heating it at $60^{\circ} \mathrm{C}$ for $2 \mathrm{~h}$ inside a vessel containing 4 drops of formalin. The retina remained in the vessel for another $24 \mathrm{~h}$, and then we took pictures with a Panasonic Lumix FZ28 digital camera to calculate and correct for tissue shrinkage during staining [Stone, 1981; Hart, 2002].

The retina was then cleared for $20 \mathrm{~min}$ in two 10 -min changes of Histo-Clear (National Diagnostics), followed by two 2-min rinses in each of the following solutions: $100 \%$ ethanol, another $100 \%$ ethanol, $95 \%$ ethanol acidified with glacial acetic acid, $80 \%$ ethanol, 70\% ethanol, and distilled water acidified with glacial acetic acid. We immersed the retina in $0.25 \%$ cresyl violet for approximately $12 \mathrm{~min}$, and then quickly rinsed it in acidified distilled water, and dehydrated it in 70\% ethanol and $80 \%$ ethanol, each for $30 \mathrm{~s}$. We placed the retina in $95 \%$ ethanol acidified with acetic acid for $60 \mathrm{~s}$, followed by two rinses in $100 \%$ ethanol each for $60 \mathrm{~s}$. The tissue was differentiated in 95\% ethanol acidified with acetic acid until clear. This was followed by two quick rinses in $100 \%$ ethanol, and the tissue was then placed back in HistoClear for two 10-min rinses [Stone, 1981; Boire et al., 2001; Hart, 2002]. We coverslipped the tissue with Permount (Fisher Scientific) and allowed it to dry, upon which we took postprocessing pictures to estimate tissue shrinkage.

ImageJ (http://rsb.info.nih.gov/ij/) was used to measure the area of the retina before and after processing. The area captured in the pictures was $0.01 \mathrm{~mm}^{2}$, so the correction for tissue shrinkage was $0.01+(0.01 \times$ proportion of shrinkage $)$. The correction was done on each retina. Cell density was calculated by dividing the number of cells in each picture by the corrected tissue area of each picture.

Stained retinal ganglion cells were examined under a microscope (Olympus BX51) at $\times 40$ power. We traced the perimeter of the retina using Stereo Investigator (ver. 9.13; MBF Bioscience), and used the SRS Image Series Acquire module, which uses a fractionator approach by which the program randomly and systematically places a grid onto the traced retina. We used a mean of $254 \pm 3.43$ grid sites per retina, although we could not measure cell density from all of them (see Results). A $100 \times 100 \mu \mathrm{m}$ counting frame was placed in the upper left hand corner of each grid site to avoid double counting. We estimated the following parameters in Stereo Investigator: asf (the ratio of the area of the counting frame to the area of the grid) $=0.0050 \pm 0.0003$ per retina; tsf (ratio of the height of the dissector to the mean measured tissue thickness) $=1$ per retina, and $\Sigma Q^{-}$(sum of the total number of retinal ganglion cells) $=7,000 \pm 425.2$ per retina. On a given counting frame, we focused on the plane that would provide the highest resolution and contrast to differentiate retinal ganglion cells, and took a picture with a microscope camera (S97809; Olympus). We captured these images using SnagIt (www.techsmith.com/Snagit), and counted the retinal ganglion cells in each of the counting frame images with ImageJ to estimate the density (number of cells $/ \mathrm{mm}^{2}$ )

The retinal ganglion cell layer can also include other cell types, such as amacrine and glial cells. Ganglion cells were identified based on standard criteria: their shape, relatively large soma size, Nissl accumulation in the cytoplasm, and staining of the nucleus [Hughes, 1977; Freeman and Tancred, 1978; Ehrlich, 1981; Stone, 1981; Rahman et al., 2006]. In retinal regions with higher cell density, ganglion cell soma size was small and showed a darkly stained nucleus. In the perifoveal and retinal periphery area, ganglion cells showed a prominent nucleus and a heterogeneous distribution of Nissl granules. Glial cells were usually oblong, narrow and very elongated with deep Nissl accumulation. Amacrine cells were small teardrop-shaped cells with deep Nissl accumulation.

We followed Stone [1981] in building the topographic maps, which reflect variations in the density of retinal ganglion cells across the retina. We plotted the cell density values obtained from each counting frame into a map of the sampling grid produced by Stereo Investigator using OpenOffice Draw (www.openoffice. org). We used six preselected cell density ranges $(0-1,999 ; 2,000-$ 3,$999 ; 4,000-5,999 ; 6,000-7,999 ; 8,000-9,999$, and $\geq 10,000$ cells/ $\mathrm{mm}^{2}$ ). Within a given cell density range, we interpolated the isodensity line from one or more adjacent density values (e.g., a line was drawn between any two sampling frames in which cell densities straddled a given cell density range). Isodensity lines were created by hand [Stone, 1981; Moroney and Pettigrew, 1987; Wathey and Pettigrew, 1989]. Additionally, we measured the pro- 
portional area of each cell density range in each of the five retinas studied to characterize their relative contribution to the overall visual resolution of the retina.

\section{Visual Field Configuration and Eye Movement}

We measured the visual field configuration of Canada geese with a visual field apparatus [Martin, 1984]. Individuals were restrained at the center of the apparatus in a horizontal position. The bill was placed in a goose-adapted metal bill holder to keep the head from moving. The head was held at an angle geese naturally assume (dorsal portion of lower mandible parallel to the ground), based on pictures and videos of individuals taken in the wild. The configuration of the visual field was measured using an angular coordinate system, in which the head of the goose was positioned at the center of a global space (see Results), with the horizontal axis of the globe projecting through both eyes. In this coordinate system, $0^{\circ}$ elevation lay directly above the head of the goose, $90^{\circ}$ lay in front of the head, and $270^{\circ}$ lay behind the head. The $90-270^{\circ}$ plane was defined as the horizontal plane parallel to the ground (see Results).

We measured the retinal visual field using an ophthalmoscopic reflex technique that has been extensively employed in comparative visual ecology [Martin, 2007]. We mathematically adjusted our measurements to correct for close viewing following Martin [1984]. The retinal margins of each eye were measured at each elevation in $10^{\circ}$ increments using a Keeler Professional ophthalmoscope, to an accuracy of $\pm 0.5^{\circ}$. Measurements could only be taken from 140 to $260^{\circ}$ due to obstructions of the apparatus or the animal's body.

Different bird species vary considerably in their degree of eye movement [Martin, 2007; Fernández-Juricic et al., 2008; Blackwell et al., 2009; Gall and Fernández-Juricic, 2010], which can substantially change the width of the binocular and blind areas when individuals converge or diverge their eyes from the eyes-at-rest position. Consequently, we measured visual fields with two different methods: (1) when the eyes were at rest, and (2) when eyes were converged and diverged. Out of the 11 individuals, only 4 were exposed to both methods. To measure the visual field with the eyes at rest, we took measurements when the eyes were visibly relaxed and not tracking the motion of the ophthalmoscope. The projection of the pecten, a vascular structure in the avascular avian retina that projects a blind area into the visual field, was also measured [Meyer, 1977; Fernandez-Juricic et al., 2008]. Ten geese were measured with eyes at rest. In the second method, we elicited eye movements by presenting sounds and/or flashes of light across all elevations around the bird's head. We recorded the maximum (eyes converged) and minimum (eyes diverged) positions of the retinal field margins at different elevations; the difference representing the degree of eye movement. We also calculated the maximum and minimum size of the binocular, blind, lateral [360 - (mean blind field + mean binocular field)/2] and cyclopean (binocular + lateral right + lateral left visual fields) areas [Fernández-Juricic et al., 2008]. Nine geese were measured with the eyes converged/diverged.

\section{Head Movement}

We made video recordings of Canada geese (B. canadensis maxima subspecies) in rural and suburban areas in the Greater Lafayette area (Ind., USA) using a JVC Everio GZ-MG330-HU camcorder between 08.00 and $17.00 \mathrm{~h}$ in January and February 2010. We searched for individuals in areas close to bodies of water.
We avoided the possibility of resampling the same individual by keeping track of the individuals that had been recorded on a given session or by moving at least $50 \mathrm{~m}$ in the opposite direction of the last individual that was video-taped. After recording the video, we measured ambient temperature, flock size, distance between the observer and the bird, and the percentage of tree cover in a 50-m-diameter circle around the bird. Temperature and flock size were recorded because they can potentially influence vigilance behavior in geese [Mowbray et al., 2002]. Temperature was measured with a handheld weather station (Kestrel 3500) and distances with laser range finders (Bushnell Yardage Pro and Bushnell Yardage Pro Sport). Overall, we recorded and analyzed 30 video recordings of Canada geese on the ground scanning and looking for food. Mean video duration was $2.21 \pm 0.22 \mathrm{~min}$.

We used JWatcher [Blumstein and Daniel, 2007] to measure head movements. First, we measured any kind of head movement when the head was above the horizontal plane of the body (total head movement rate) and moved along a single axis, and the direction of the eye-bill tip vector followed the head movement. We used these data to assess the effects of visual obstruction (e.g., tree cover) on head movement behavior. We report head movements per minute.

Second, after obtaining the results on the orientation of the visual streak, we reanalyzed all the videos but separated the head movements (while the head was above the horizontal plane of the body) according to three head orientations: bill parallel to the ground, bill tilted downwards, and bill tilted upwards. In the bill parallel to the ground orientation, we recorded sideways head movements. In the bill tilted downwards orientation (below the horizontal plane of the head but above the horizontal plane of the body), we recorded head movements with (1) the neck static and the head moving sideways and (2) with the neck and the head moving in the same direction. In the bill tilted upwards orientation (above the horizontal plane of the head), we recorded head movements indicative of alarm [e.g., head raising, head flicking, and head whirling following Mowbray et al., 2002]. The goal of this post hoc analysis was to determine the frequency of use of head positions that would indicate different alignments of the visual streak in relation to the horizon. We report the rates (events/ min) of head movements in the three bill orientations. This second analysis was more descriptive and necessarily made use of multiple categories of head movement (based on the relative position of the visual streak) that were not considered in the first video analysis. Hence, a higher number of head movements per minute were obtained compared to the first analysis.

\section{Statistical Analysis}

We analyzed variations in the percentage area of the total retina occupied by different retinal ganglion cell density ranges with an ANOVA. We excluded the $\geq 10,000$ cells $/ \mathrm{mm}^{2}$ cell density range from this analysis, because it was not represented in one of the retinas studied, so percentages did not add up to $100 \%$. We used a general linear model to assess the relationship between total head movement rate and tree cover, and added to the model flock size, temperature, and distance between the observer and the bird as potentially important covariates. We assessed differences between head movement rates in different bill positions with a MANOVA. We analyzed our data with Statistica 9.0, and presented means \pm SE throughout. 


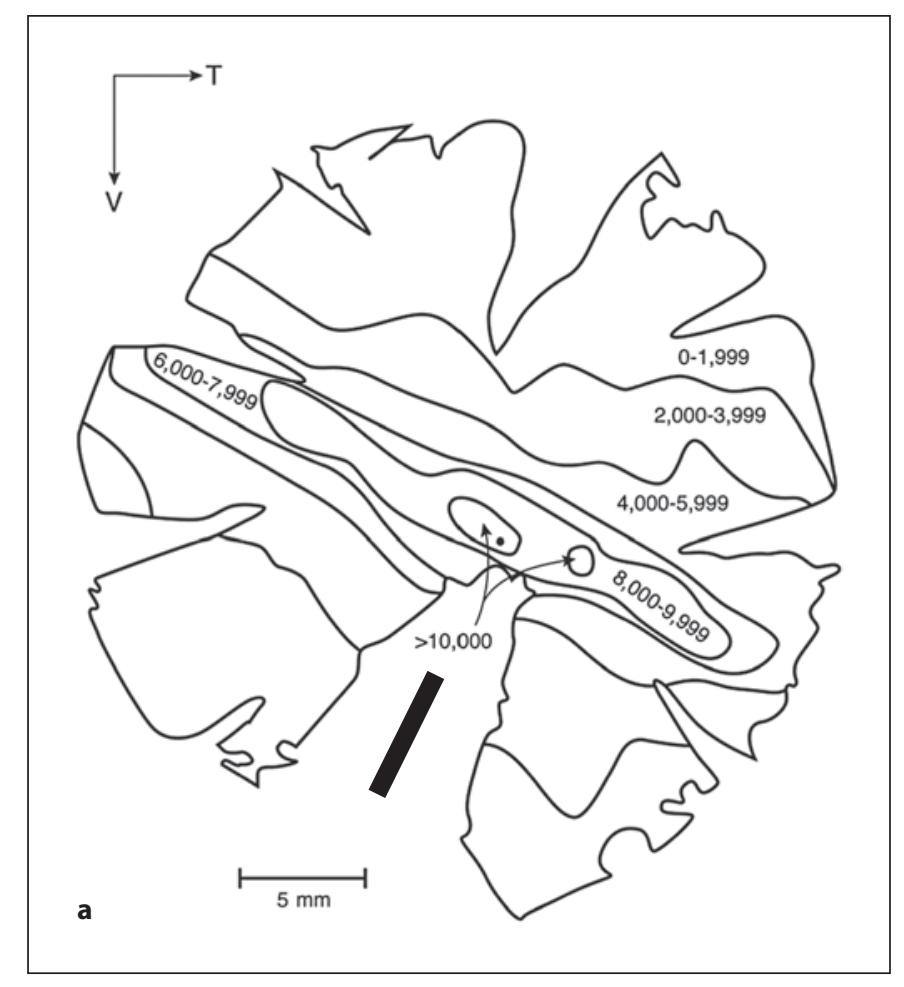

\section{Results}

Eye Size, Retinal Ganglion Cell Layer and Topography

We were able to successfully process five retinas (3 right eyes, 2 left eyes). Pooling the information on the right and left eyes, we found that the corneal diameter was $13.11 \pm 0.18 \mathrm{~mm}$, the transverse eye diameter was 21.23 $\pm 0.28 \mathrm{~mm}$, and the axial length was $15.94 \pm 0.29 \mathrm{~mm}$.

We were able to quantify the density of retinal ganglion cells from $232.60 \pm 5.24$ quadrats per individual retina. The mean overall density of retinal ganglion cells was 3,029.59 \pm 70.80 retinal ganglion cells per $\mathrm{mm}^{2}$. The mean peak density was $11,343.27 \pm 1,213.51$ retinal ganglion cells per $\mathrm{mm}^{2}$.

The topographic maps from all the retinas processed revealed a visual streak crossing the whole retina with densities $>6,000$ retinal ganglion cells per $\mathrm{mm}^{2}$ (see example in fig. 1a). Cell densities within the visual streak were higher than above or below it. However, the visual streak was not horizontal, as predicted, but oblique, with an angle of approximately $30^{\circ}$ in relation to the plane parallel to the bill, running from a dorsonasal to a ventrotemporal position (fig. 1a). The peak cell density $(>10,000$ cells per $\mathrm{mm}^{2}$ ) was found in two locations at the center of the retina. We also identified a structure that visually ap-

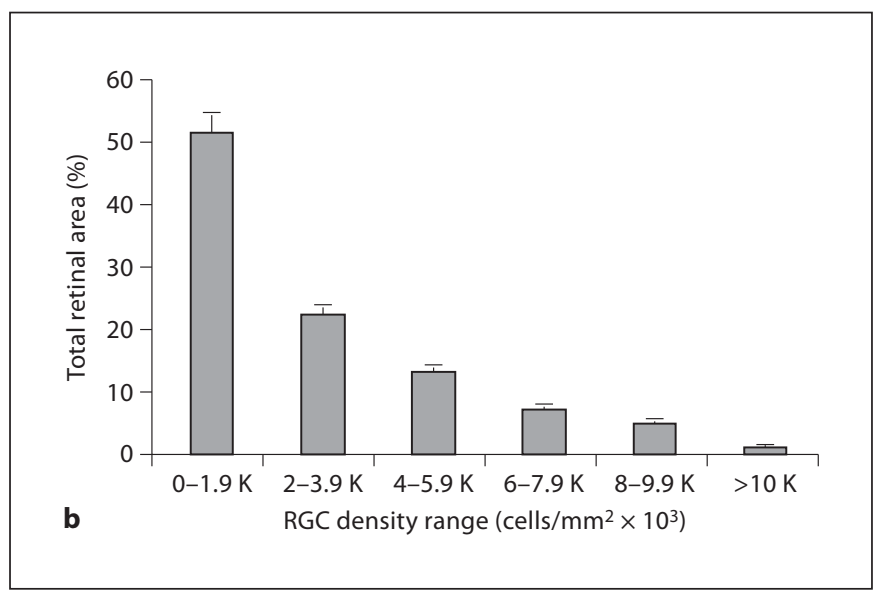

Fig. 1. a Example of a retinal topographic map of the Canada goose (left eye). Numbers represent ranges of retinal ganglion cell (RGC) density $\left(\right.$ cells $/ \mathrm{mm}^{2}$ ). The pecten is indicated by the black line in the lower half of the diagram. $\mathrm{V}=$ Ventral; $\mathrm{T}=$ temporal. The presence of a potential fovea is indicated by the black dot in the central retina. $\mathbf{b}$ Average percentage of the retinal area in different cell density ranges $\left(\right.$ cell $\left./ \mathrm{mm}^{2} \times 10^{3}\right)$.

peared to be a fovea also at the center of the retina (black dot in fig. 1a). However, we did not do transverse sectioning to confirm that the retina was pitted and the retinal ganglion cells were peripherally displaced. We confirmed the position of the visual streak in geese by establishing the position of the pecten in relation to other skull features while the eye was still in the orbit and also examining the position of the pecten ophthalmologically in live individuals.

The distribution of ganglion cell densities was heterogeneous in the Canada goose retina (fig. 1b). Retinal ganglion cell density ranges varied significantly in the percentage of the total area occupied $\left(\mathrm{F}_{4,20}=94.31, \mathrm{p}<\right.$ $0.001)$. The majority $(>50 \%)$ of the goose retina was occupied by the lowest retinal ganglion cell density range, with a progressive decrease in proportional coverage towards the area with the peak cell density (fig. 1b), which corresponded with the visual streak (fig. 1a).

\section{Visual Fields}

At Rest Visual Fields

The bill tip projected into the binocular field just below the horizontal plane (elevation $80^{\circ}$, fig. $2 \mathrm{a}$ ). In the horizontal plane (plane of the bill, $90-270^{\circ}$ ), the width of the binocular field was $22^{\circ}$ (fig. $2 \mathrm{~b}$ ). The maximum width 
Fig. 2. Visual fields of Canada geese with the eyes at rest. a Orthographic projection of the boundaries of the retinal fields of the two eyes, along with projection of the pecten and bill tip. A latitude and longitude coordinate system was used with the equator aligned vertically in the median sagittal plane. The bird's head is imagined to be at the center of the globe (grid is at approximately $20^{\circ}$ intervals). The dotted lines represent the extrapolated binocular field assuming that the retinal margin follows a circular projection (see text). Values from different individuals were used to depict this representation. b Horizontal section through the horizontal plane showing the visual field configuration. c Binocular overlap and blind areas across elevations around the head. Mean ( \pm SE) angular separation of the retinal field margins as a function of elevation in the median sagittal plane. Binocular fields are indicated by positive values of overlap of the visual field margins, whereas blind areas are indicated by negative values. The horizontal plane in b and $\mathbf{c}$ is represented by $90^{\circ}$ (front of the head) to $270^{\circ}$ (back of the head), with $0^{\circ}$ indicating a position above the head.

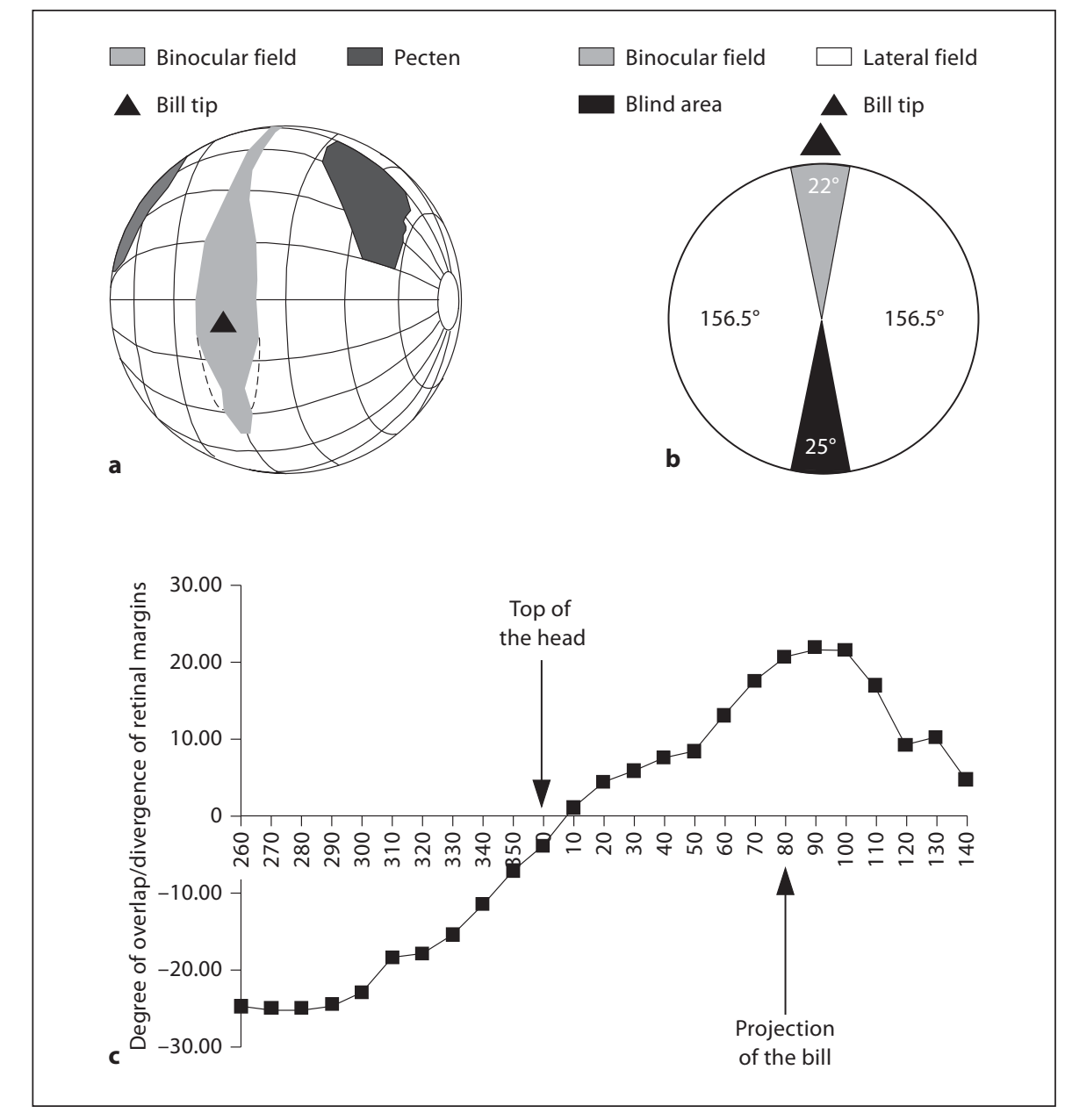

of the binocular field when the eyes were at rest $\left(22.01^{\circ}\right)$ occurred at elevation $90^{\circ}$ (fig. 2c). At elevations $110-130^{\circ}$ (below the plane of the bill; fig. 2a), the bill blocked the view of the retinal margins, suggesting that individuals were able to observe their bill tips. The extrapolated width of the binocular field at elevations $110-130^{\circ}$ was estimated to be $22^{\circ}$, assuming that the retinal margin follows a circular projection [Martin and Coetzee, 2004]. Across the recorded elevations, the average width of the binocular field was $11.67 \pm 1.91^{\circ}$ with the eyes at rest. The binocular field extended vertically from $140^{\circ}$ (just below the bill) to $10^{\circ}$ (just below the top of the head), totaling at least $130^{\circ}$ of vertical extent (fig. 2c). We were not able to record below $140^{\circ}$ due to the visual field apparatus obstructing our measurements.

At the horizontal plane (plane of the bill, $90-270^{\circ}$ ), the width of the blind area was $25^{\circ}$ (fig. 2b). The maximum width of the blind area $\left(25^{\circ}\right)$ occurred at elevations $270^{\circ}$ and $280^{\circ}$ (rear of the head) with the eyes at rest (fig. 2c). Across the recorded elevations, the average width of the blind area was $17.87 \pm 3.21^{\circ}$. The blind area extended vertically from $260^{\circ}$ (rear of the head) to $0^{\circ}$ (above the head; fig. 2c). Below elevation $260^{\circ}$, we were not able to record due to the goose body obstructing our measurements.

In the horizontal plane with the eyes at rest, the lateral field extended $156.50^{\circ}$ (fig. $2 \mathrm{~b}$ ) and the total visual coverage (cyclopean visual field $=$ binocular + lateral left eye + lateral right eye) was $334^{\circ}$ (fig. 2b). Across the recorded elevations, the average width of the pecten was $24.93 \pm 2.28^{\circ}$, extending vertically from 70 to $10^{\circ}$ (fig. $2 \mathrm{a}$ ).

Degree of Eye Movement and Visual Fields with Converged and Diverged Eyes

Eye movements varied at different elevations around the head. The maximum degree of eye movement was re- 
Fig. 3. Eye movements and resultant changes in the configuration of the visual fields in Canada geese. a Average degree of eye movements as a function of elevation in the median sagittal plane. Elevations are envisioned as if viewing the head of the bird from the left side, with the bill projecting at approximately $80^{\circ}$. In this coordinate system, $90^{\circ}$ lay in front of the head and $270^{\circ}$ lay behind the head. The $90-270^{\circ}$ plane is defined as the horizontal plane, whereas the $0^{\circ}$ elevation lay directly above the head of the goose. The units within the radial plot are in degrees. b Orthographic projection of the boundaries of the retinal fields of the two eyes, which along with projection of the bill tip shows with dotted lines the extrapolated binocular field around the bill assuming that the retinal margin follows a circular projection. c, d Horizontal sections through the horizontal plane $\left(90-270^{\circ}\right)$ showing the visual field configuration when the eyes were fully converged (eyes rotated fully forward; c), which maximizes the size of the binocular and blind areas, and fully diverged (eye rotated fully backward; d), which minimizes the size of the binocular and blind areas.

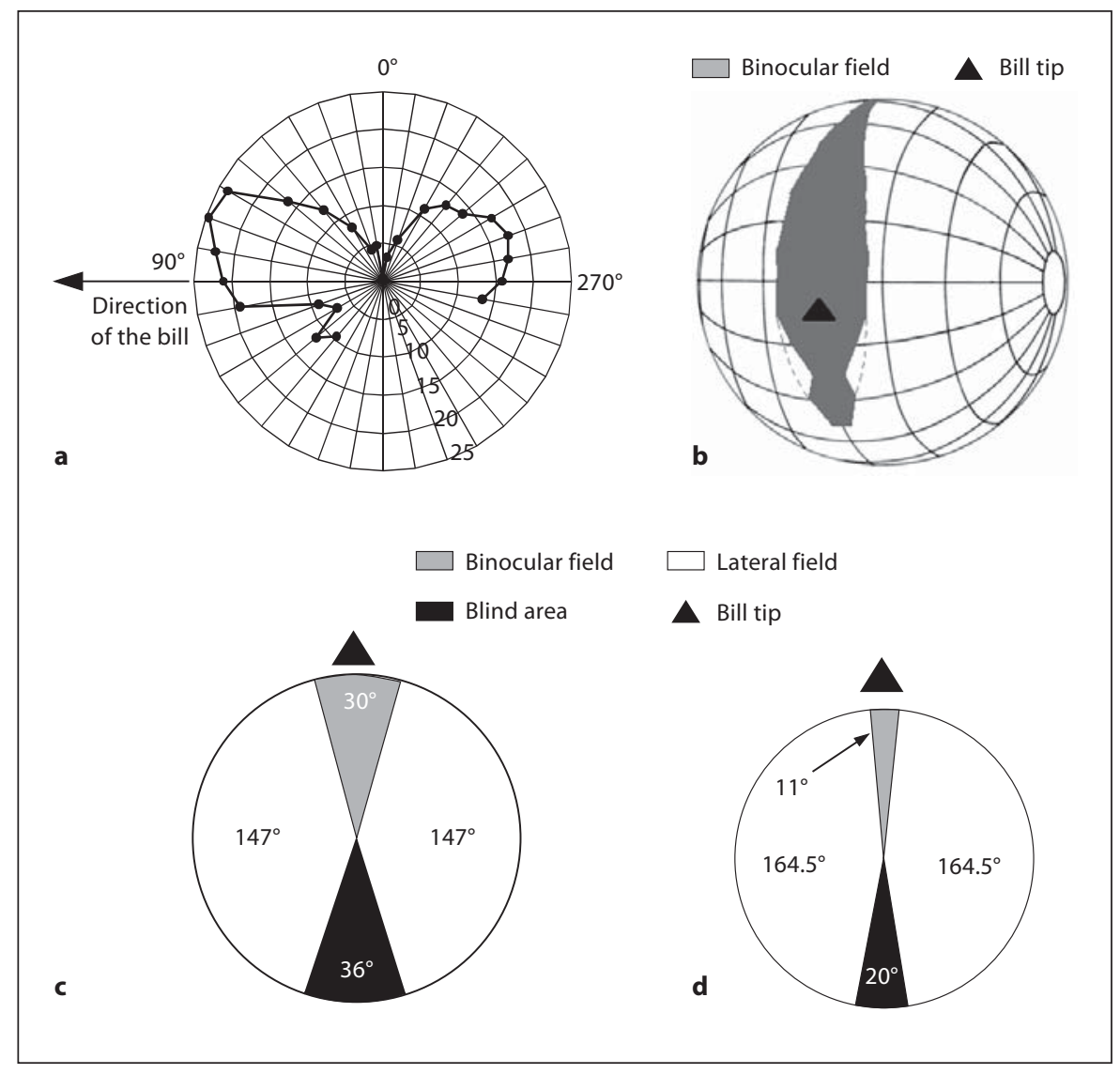

corded at elevation $70^{\circ}\left(24.57^{\circ}\right.$; fig. 3a). Canada geese showed a higher degree of eye movement above than below the plane of the bill. The elevation where this higher degree of eye movement occurred appears to be in an orientation similar to the dorsonasal positioning of the visual streak (fig. 1a, 3a). Across the recorded elevations, the average degree of eye movement was $12.87 \pm 1.82^{\circ}$.

With the eyes converged, the binocular field increased $8^{\circ}$ in relation to the eyes-at-rest position in the horizontal plane (fig. 3c). Actually, when geese converged their eyes, the bill intruded enough in the binocular field to block our view of the retinal margins at elevations $110-130^{\circ}$ (below the plane of the bill; fig. 3b), suggesting that individuals were also able to observe their bill tips at those elevations. The extrapolated width of the binocular field at elevations $110-130^{\circ}$ was estimated to be $28^{\circ}$, assuming that the retinal margin follows a circular projection [Martin and Coetzee, 2004]. Additionally, with the eyes converged, the blind area also increased $11^{\circ}$ in relation to the eyes-at-rest-position in the horizontal plane (fig. 3d). Overall, eye convergence resulted in a reduction of the cyclopean visual field at the horizontal plane to $324^{\circ}$, causing a decrease in the widths of the lateral fields due to the increased blind area behind the head.

When Canada geese diverged their eyes, the width of the binocular field and blind area decreased by 11 and $5^{\circ}$, respectively, in relation to the eyes-at-rest-position (fig. 3c, d). Overall, eye divergence resulted in an increase of the cyclopean visual field to $340^{\circ}$.

\section{Scanning Behavior}

The total head movement rate was $19.88 \pm 1.94$ events $\mathrm{min}^{-1}$. Total head movement rate was not significantly affected by flock size $\left(\mathrm{F}_{1,25}=1.06, \mathrm{p}=0.312\right.$; range: $1-200$ individuals), temperature $\left(\mathrm{F}_{1,25}=0.09, \mathrm{p}=0.768\right.$; range: -5.4 to $21.7^{\circ}$ ), or distance between the focal bird and the observer $\left(\mathrm{F}_{1,25}=0.45, \mathrm{p}=0.508\right.$; range: $\left.15-105 \mathrm{~m}\right)$. However, total head movement rate increased significantly with an increase in tree cover $\left(\mathrm{F}_{1,25}=21.75, \mathrm{p}<0.001\right.$; fig. 4).

We also characterized the rate and proportion of time Canada geese performed head movements in different 


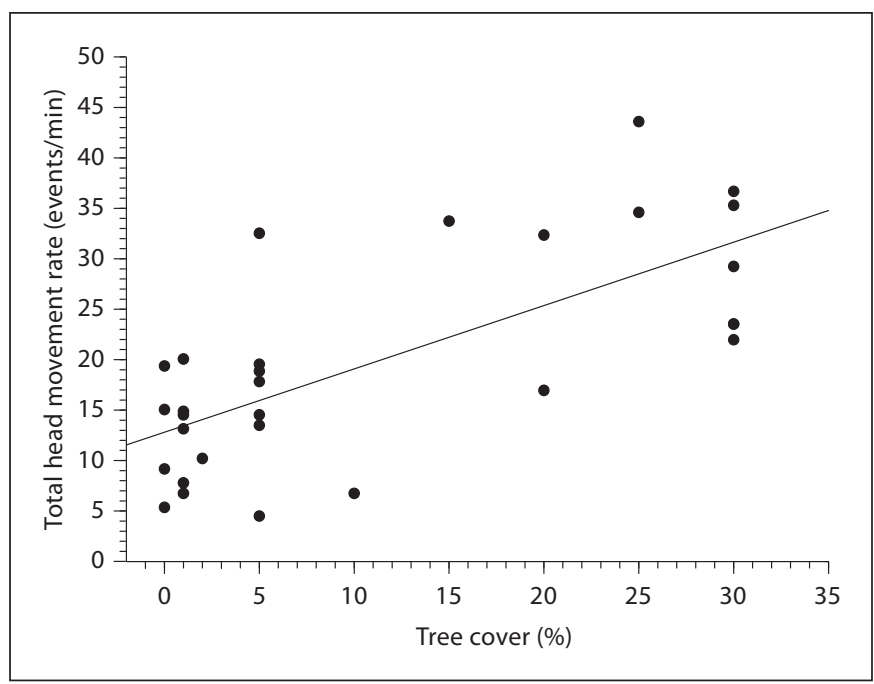

Fig. 4. Relationship between Canada goose total head movement rate (events/min) and the percentage of tree cover.

bill positions. There was significant variation in head movement rates in different head positions (Wilks $=0.21$, $\mathrm{F}_{3,27}=34.51, \mathrm{p}<0.001$ ), with geese moving their heads more often when the bill was parallel to the ground (12.94 \pm 2.22 events $\left.\mathrm{min}^{-1}\right)$ and tilted downwards $(12.42 \pm 1.88$ events $\left.\mathrm{min}^{-1}\right)$ than when the bill was tilted upwards (0.04 \pm 0.02 events $\left.\mathrm{min}^{-1}\right)$. This finding suggests that geese have a similar rate of head moving with the bills parallel to the ground and tilted downwards.

\section{Discussion}

Our results generally agree with the terrain hypothesis. First, we found Canada geese to have a visual streak as indicated by the retinal topography of the ganglion cell layer. Second, Canada geese have large lateral visual fields and narrow blind areas that increase visual coverage. Third, habitat visual obstruction increased head movement behavior, which is likely a compensatory mechanism for reduced visual coverage. However, contrary to the terrain hypothesis, we found that the visual streak was obliquely rather than horizontally placed. This is an interesting result given that other species within the Anatidae family have been found to have horizontal streaks [mallard, Anas platyrhynchos; white-winged scoter, Melanitta deglandi; long-tailed duck Fuligula glacialis; snow goose, Anser hyperboreus; Chievitz, 1891; Slonaker, 1897; Wood, 1917]. Furthermore, the degree of eye move- ment in Canada geese was not as low as that found in other species of the Anatidae family [Martin, 1986; Guillemain et al., 2002; Martin et al., 2007]. Finally, we found that Canada geese were able to see their bill tips below the plane of the bill, which is not necessarily expected from species that forages on passive prey [Martin, 2009].

There are some old accounts of retinal specializations obtained through macroscopic and ophthalmoscopic inspections of the eyes that reported oblique ribbon-like structures in the retinas of some species from different families: Brandt's cormorant (Phalacrocorax penicillatus), herring gull (Larus argentatus), Eurasian coot (Fulica atra), black-bellied plover (Squatarola squatarola), American flamingo (Phoenicopterus ruber), Eurasian oystercatcher (Haematopus ostralegus), and Northern lapwing (Vanellus vanellus) [Wood, 1917; Duijm, 1958]. However, to our knowledge, ours is the first study to report the presence of an oblique visual streak in a bird based on the assessment of the retinal ganglion cell layer. All these species share their dependency on water bodies in open habitats in either freshwater or marine environments. Duijm [1958] proposed that in birds with an oblique visual streak, the normal head position would have the bill pointing downwards so that the plane of the lateral semicircular canal, used for orientation in space, is held horizontal. Such a head position would align the visual streak with the horizon, as predicted by the terrain hypothesis. When scanning, we actually found that Canada geese do tilt their bills downwards as frequently as they hold their bills parallel to the ground. This suggests that this species gathers visual information horizontally as well as obliquely, by varying head position.

Visual resolution is expected to be higher along the visual streak than in other parts of the retina. The visual streak would affect information gathering depending on the position of the bill. When the bill of the Canada goose is parallel to the ground, visual resolution would be higher from the upper part of the binocular field (above the plane of the bill) to the rear of the head (below the plane of the body). This head position would allow individuals to see the ground and the sky simultaneously, which can enhance detection of targets of interest in two dimensions (food, predators, conspecifics). The detection of aerial predators approaching from the front could be enhanced; however, this combination of retinal configuration and head position would decrease the chances of detecting predators approaching from the rear of the animal. In fact, documented cases of successful attacks emphasize raptors grabbing Canada geese by their backs [McWilliams et al., 1994]. Canada geese maintain a simi- 
Fig. 5. Orientation of the oblique visual streak in different Canada geese head positions. a Individuals head-up scanning with the bill parallel to the ground. b Individuals with the bill tilted downwards towards the ground. c Individuals head down searching for food on the ground and in water. We assumed the head position while under water as it has not been measured to our knowledge.

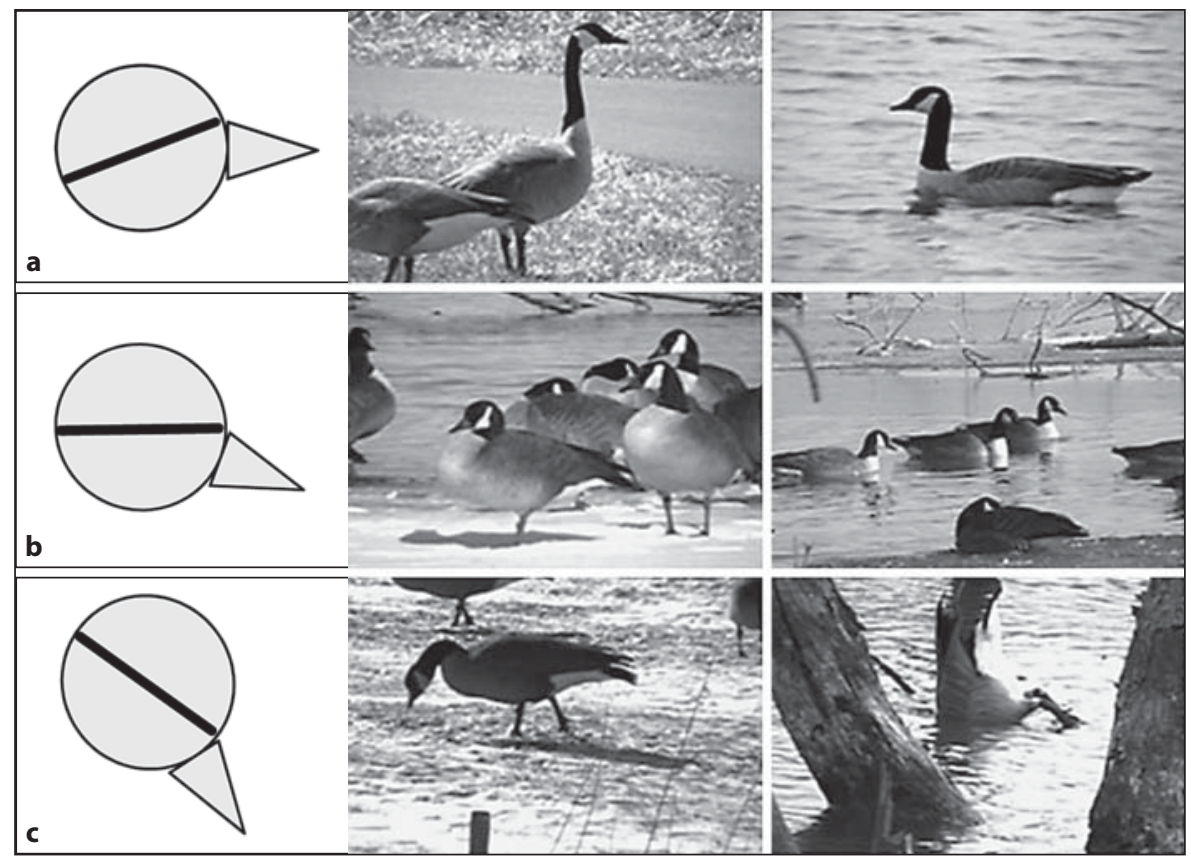

Table 1. Degree of eye movement and head movement rate in five bird species with different types of retinal specializations: Canada goose, red-tailed hawk, American kestrel, California towhee, and white-crowned sparrow

\begin{tabular}{llcll}
\hline Species & Retinal specialization & $\begin{array}{l}\text { Degree of eye } \\
\text { movement }\end{array}$ & $\begin{array}{l}\text { Head movement Reference } \\
\text { rate events/min }\end{array}$ \\
\hline Canada goose & visual streak and fovea & $12.87 \pm 1.82^{\circ}$ & $19.88 \pm 1.94$ & this study \\
Red-tailed hawk & central and temporal foveae & $4.90 \pm 0.40^{\circ}$ & $19.33 \pm 3.34^{\mathrm{b}}$ & O’Rourke et al., 2010a, b $^{\prime}$ \\
American kestrel & central and temporal foveae & $0.88 \pm 0.30^{\circ}$ & $18.10 \pm 1.51^{\mathrm{b}}$ & O’Rourke et al., 2010a, b $^{\circ}$ \\
California towhee & central fovea displaced temporally & $10.61 \pm 0.39^{\circ}$ & $89.65 \pm 7.35^{\mathrm{c}}$ & Fernández-Juricic et al., 2011 \\
White-crowned sparrow & central fovea displaced temporally & $12.17 \pm 0.46^{\circ}$ & $63.05 \pm 4.88^{\mathrm{c}}$ & Fernández-Juricic et al., 2011
\end{tabular}

All the species presented here have known retinal topography.

a Overall degree of eye movement across all elevations in the visual field, as measured with an ophthalmoscopic reflex technique.

${ }^{\mathrm{b}}$ Head movement behavior measured on individuals perching in trees.

${ }^{\mathrm{c}}$ Head movement behavior measured on individuals on the ground within an enclosure.

lar head position (bill parallel to the ground) while flying probably to reduce drag. In that case, the oblique visual streak could allow individuals to enhance the detection of visual landmarks by being able to see the ground as they move forward, along with keeping track of conspecifics if they are in a nonplanar $\mathrm{V}$ flying formation [Badgerow, 1988]. The oblique visual streak would also allow flying Canada geese to detect predators from within the rear and lower parts of their visual fields, as bald eagles attack them from below while performing somersault maneuvers [Stalmaster, 1987].
When the bill of the Canada goose is tilted downwards while head up, visual resolution would be higher laterally and horizontally, as the oblique visual streak would be aligned parallel to the horizon. This head position would allow individuals to enhance visual resolution and detection of objects at the interface between the ground and the sky, as predicted by the terrain hypothesis [Hughes, 1977]. This downwards bill tilting could also allow for scanning the horizon with one eye while sleeping [e.g., mallards, Rattenborg et al., 1999], as Canada geese sleep with the head low above their chest or 
with the neck stretched to the back of the body and the bill between the scapulars [Mowbray et al., 2002] (fig. 5). Further changes in head orientation can enhance visual resolution of different sectors of the visual space. For instance, when geese search for food or peck, they can increase resolution at the back of their heads to detect potential predators, and when consuming submerged vegetation, they could potentially enhance visibility of the water column (fig. 5). Overall, retinal topography and variations in head position would maximize visual resolution in different planes of the visual field. Future behavioral experiments could tease apart some of these interpretations by manipulating the position of animals in space and assessing their performance in different visual tasks.

Our functional interpretation of the oblique visual streak assumes that predation risk is an important factor in the behavior of Canada geese. There is evidence showing that Canada geese spend a considerable amount of their daily activities in vigilance and respond to predator attacks by flying away or seeking refuge in the water [Mowbray et al., 2002]. Canada geese mortality by eagles varies spatially and temporally in their wintering grounds with up to one individual killed every 3 days in some localities [McWilliams et al., 1994]. Goose mortality due to predation increases with the density of individuals, the reduction in abundance of alternative prey, and is particularly high immediately after migration, when individuals have lower energy reserves and thus are less likely to escape an attack successfully [McWilliams et al., 1994].

The topographical analysis of the Canada goose retina showed that the lowest retinal ganglion cell density range occupied the largest percentage of the total retinal area, with a consistent decrease in the proportional area of the retina occupied by higher cell density ranges. This pattern suggests that most of the high visual resolution is provided by the visual streak across the center of the retina. However, in species with a single area of high ganglion cell density, the retinal topography is different: the highest proportion of retinal area is occupied by intermediate (rather than the lowest) cell density ranges [Dolan and Fernández-Juricic, 2010; Fernández-Juricic et al., 2011]. One of the implications of this difference is that movements of the eyes and the head to scan the visual space would differ between species with different types, position, and number of retinal specializations [Fernández-Juricic et al., 2011]. This is because retinal areas of high acuity project into a limited portion of the visual field, leaving spots of low acuity that need to be moni- tored by moving the retinal specialization with the eyes and/or the head. Therefore, these movements could vary in amplitude depending on the proportional area of the retina with high and low visual resolution. Future studies should assess the relationship between retinal specialization and head and eye movements at the comparative level controlling for phylogenetic effects. The number of species with information on both retinal topography and scanning behavior is relatively scant (see below), but we can still make some simple comparisons.

For instance, the proportional area of highest retinal acuity is expected to occupy a proportionally larger retinal area in species with a visual streak (e.g., Canada geese) or two foveae (e.g., diurnal raptors) than in species with a single small high-acuity spot (e.g., fovea) in the retina (e.g., some songbirds). Having an elongated area, or multiple areas, of high acuity may reduce the need to move the head because of the relatively lower proportion of the visual field with low acuity (table 1). However, species with an elongated area or multiple areas seem to be affected by visual obstruction in the habitat, likely because the heterogeneity of the visual space (compared to open habitat) requires adjustments in head movements to focus on different planes. For example, black phoebes Sayornis nigricans increase their head movement rates before launching an attack when in territories with high tree cover [Gall and Fernández-Juricic, 2009]. In much the same way, Canada geese increased total head movement rates with increasing tree cover, probably to maintain a minimum level of visual monitoring or to increase vigilance because of higher perceived predation risk (e.g., predators hiding in the vegetation). Interestingly, the degree of eye movement of Canada geese was more similar to the two species with a single retinal area of high acuity than to the raptors with two foveae (table 1). We speculate that the higher than expected degree of eye movement of Canada geese may compensate for them having an oblique visual streak. Eye movements may let geese fine-tune the projection of the streak in visual space, particularly when the bill is parallel to the ground. Alternatively, eye movement in Canada geese may be associated with converging the eyes to increase the width of the binocular area for foraging purposes or diverging the eyes to reduce the extent of the blind area and enhance visual coverage while vigilant.

The width of the binocular field of Canada geese with the eyes at rest $\left(22^{\circ}\right.$ in the horizontal plane) resembles estimates of a previous study done using dead geese [Heppner et al., 1985]. Moreover, the width of the binocular field is similar to that of other species of water- 
birds in the same and different families [mallard, Martin, 1986; woodcock Scolopax rusticola, Martin, 1994; pink-eared duck Malacorhynchus membranaceus, Martin et al., 2007; shoveler Anas clypeata, Guillemain et al., 2002], which do not require a precise control of the bill position in relation to food items because they rely mostly on tactile cues. However, when Canada geese converge their eyes, they increase considerably the width of the binocular field ( $30^{\circ}$ in the horizontal plane), the bill is positioned at the center of the binocular area, and they can see their bill tips particularly below the plane of the bill, which would allow individuals to see a food item between their lower mandibles. This configuration is similar to that of the binocular field of the blue duck [Hymenolaimus malacorhynchos, Martin et al., 2007], a species that forages on aquatic invertebrates. However, in the case of the Canada goose, the emphasis on visually inspecting the bill may be related to its efficient grazing technique, which is facilitated by the long and flexible neck and epidermal serrations on the bill [Mowbray et al., 2002]. The ability to inspect the bill tip visually may enhance the removal of parts of the vegetation with high nutritious value, such as seeds from grasses, submerged vegetation, rhizomes and bulbs, and kernels from corn cobs [Mowbray et al., 2002]. Interestingly, the properties of the Canada goose binocular field are not generally present in species that consume mostly plant matter [Martin, 2009].
Overall, our study shows that the visual system of Canada geese has features related to the detection of predators in open areas (visual streak, large lateral field, reduced head movements), as predicted by the terrain hypothesis. Simultaneously, Canada geese have other visual specializations (oblique streak, wide binocular fields, visualization of the bill tip) that would allow for the simultaneous monitoring of the ground and the sky and enhanced extraction and handling of food items. The oblique visual streak seems to be a very specialized feature of the retina that, combined with changes in head position, may allow individuals to enhance visual information gathering in open areas and particularly in habitats that interface between water and land. Future studies should address the functional properties of this type of visual streak in this and other avian species.

\section{Acknowledgements}

This project was partially funded by US Department of Agriculture, Animal and Plant Health Inspection Service, Wildlife Services, National Wildlife Research Center and the US Federal Aviation Administration under Interagency Agreement DTFACT-09-X-90001. We thank Kristen Heitman and Providence Wildlife for allowing us to examine live geese. We also thank Thomas W. Seamans, Katherine Kapernaros, Marcella Deisher, Amy Stark, Melissa Hoover, Annamarie Bustion, Brianna Burry, Peter Perno, and Kathleen Young for their help in different parts of this project.

\section{References}

Badgerow JP (1988): An analysis of function in the formation flight of Canada geese. Auk 105:749-755.

Blackwell BF, Fernández-Juricic E, Seamans TW, Dolan T (2009): Avian visual system configuration and behavioural response to object approach. Anim Behav 77:673-684.

Blumstein DT, Daniel JC (2007): Quantifying Behavior the JWatcher Way. Sunderland, Sinauer.

Boire D, Dufour J-S, Théoret H, Ptito M (2001): Quantitative analysis of the retinal ganglion cell layer in the ostrich, Struthio camelus. Brain Behav Evol 58:343-355.

Bozzano A, Collin SP (2000): Retinal ganglion cell topography in elasmobranches. Brain Behav Evol 55:191-208.

Bravo H, Pettigrew JD (1981): The distribution of neurons projecting from the retina and visual cortex to the thalamus and tectum opticum of the barn owl, Tyto alba, and burrowing owl, Speotyto cunicularia. J Comp Neurol 199:419-441.
Caithamer DF, Gates RJ, Tacha TC (1996): A comparison of diurnal time budgets from paired interior Canada geese with and without offspring. J Field Ornithol 67: 105-113.

Calderone JB, Reese BE, Jacobs GH (2003): Topography of photoreceptors and retinal ganglion cells in the spotted hyena (Crocuta crocuta). Brain Behav Evol 62:182-192.

Chievitz JH (1891): Über das Vorkommen der Area centralis retinae in den höheren Wirbeltierklassen. R Anat Entwicklungsgesch Suppl 139:311-334.

Collin SP (1999): Behavioural ecology and retinal cell topography; in Archer SN, Djamgoz MBS, Loew ER, Partridge JC, Vallerga S (eds): Adaptive Mechanisms in the Ecology of Vision. Dordrecht, Kluwer, pp 509-535.

Collin SP, Pettigrew JD (1988): Retinal topography in reef teleosts. I. Some species with well developed areae but poorly developed streaks. Brain Behav Evol 31:269-282.
Dawkins MS (2002): What are birds looking at? Head movements and eye use in chickens. Anim Behav 63:991-998.

Dolan T, Fernández-Juricic E (2010): Retinal ganglion cell topography of five species of ground foraging birds. Brain Behav Evol 75: $111-121$.

Duijm M (1958): On the position of a ribbon like central area in the eyes of some birds. Arch Neerl Zool 13:128-145.

Dunlap K, Mowrer OH (1930): Head movements and eye functions of birds. J Comp Psychol 11:99-112.

Ehrlich D (1981): Regional specialization of the chick retina as revealed by the size and density of neurons in the ganglion cell layer. J Comp Neurol 195:643-657.

Fernández-Juricic E, Gall MD, Dolan T, Tisdale V, Martin GR (2008): The visual fields of two ground-foraging birds, house finches and house sparrows, allow for simultaneous foraging and anti-predator vigilance. Ibis 150: 779-787. 
Fernández-Juricic E, Gall MD, Dolan T, O'Rourke C, Thomas S, Lynch JR (2011): Visual systems and vigilance behavior of two ground foraging avian prey species: whitecrowned sparrows and California towhees. Anim Behav 81:705-713.

Fowler AC, Ely CR (1997): Behavior of cackling Canada geese during brood rearing. Condor 99:406-412.

Freeman B, Tancred E (1978): The number and distribution of ganglion cells in the retina of the brush-tailed possum, Trichosurus vulpecula. J Comp Neurol 177:557-567.

Gall MD, Fernández-Juricic E (2009): Effects of physical and visual access to prey on patch selection and food search effort in a sit-andwait predator, the Black Phoebe. Condor 111: 150-158.

Gall MD, Fernández-Juricic E (2010): Visual fields, eye movements, and scanning behavior of a sit-and-wait predator, the Black Phoebe (Sayornis nigricans). J Comp Physiol A 196:15-22.

Guillemain M, Martin GR, Fritz H (2002): Feeding methods, visual fields and vigilance in dabbling ducks (Anatidae). Funct Ecol 16: 522-529.

Hart NS (2002): Vision in the Peafowl (Aves: Pavo cirstatus). J Exp Biol 205:3925-3953.

Hayes B, Martin GR, Brooke Mde L (1991): Novel area serving binocular vision in the retinae of Procellariiform seabirds. Brain Behav Evol 37:79-84.

Heppner FH, Convissar JL, Moonan DE Jr, Anderson JGT (1985): Visual angle and formation flight in Canada geese (Branta canadensis). Auk 102:195-198.

Hughes A (1975): A comparison of retinal ganglion cell topography in the plains and tree kangaroo. J Physiol Paris 244:61-63.

Hughes A (1977): The topography of vision in mammals of contrasting life style: comparative optics and retinal organization; in Crescitelli F (ed): The Visual System in Vertebrates. New York, Springer, pp 615-756.

Johnson GL (1901): Contributions to the comparative anatomy of the mammalian eye, chiefly based on ophthalmoscopic examination. Philos Trans B 194:1-82.
Kral K (2003): Behavioural-analytical studies of the role of head movements in depth perception in insects, birds and mammals. Behav Process 64:1-12.

Luck CP (1965): The comparative morphology of the eyes of certain African suiformes. Vision Res 5:283-297.

Martin GR (1984): The visual fields of the tawny owl, Strix aluco. Vision Res 24:1739-1751.

Martin GR (1986): Total panoramic vision in the mallard duck Anas platyrhynchos. Vision Res 26:1303-1305.

Martin GR (1994): Visual fields in woodcocks Scolopax rusticola (Scolopacidae; Charadriiformes). J Comp Physiol A 174:787-794.

Martin GR (2007): Visual fields and their functions in birds. J Ornithol 148:S547-S562.

Martin GR (2009): What is binocular vision for? A birds' eye view. J Vision 9:14, 1-19.

Martin GR, Coetzee HC (2004): Visual fields in hornbills: precision-grasping and sunshades. Ibis 146:18-26.

Martin GR, Jarrett N, Williams M (2007): Visual fields in blue ducks Hymenolaimus malacorhynchos and pink-eared ducks Malacorhynchus membranaceus: visual and tactile foraging. Ibis 149:112-120.

McIlwain JT (1996): An Introduction to the Biology of Vision. New York, Cambridge University Press.

McWilliams SR, Dunn JP, Raveling DG (1994): Predator-prey interactions between eagles and cackling Canada and Ross' geese during winter in California. Wilson Bull 106:272288.

Meyer DBC (1977): The avian eye and its adaptations; in Crescitelli F (ed): The Visual System of Vertebrates; Handbook of Sensory Physiology. New York, Springer, vol VII/5, pp 549-612.

Moroney MK, Pettigrew JD (1987): Some observations on the visual optics of kingfishers (Aves, Coraciformes, Alcedinidae). J Comp Physiol A 160:137-149.

Mowbray TB, Ely CR, Sedinger JS, Trost RE (2002): Canada goose (Branta canadensis); in Poole A (ed): The Birds of North America Online. Ithaca, Cornell Lab of Ornithology. http://bna.birds.cornell.edu/bna/species/682.

O’Rourke CT, Hall MI, Pitlik T, Fernández-Juricic E (2010a): Hawk eyes. I. Diurnal raptors differ in visual fields and degree of eye movement. PLoS ONE 5(9):e12802.
O’Rourke CT, Pitlik T, Hoover M, FernándezJuricic E (2010b): Hawk eyes. II. Diurnal raptors differ in head movement strategies when scanning from perches. PLoS ONE 5(9):e12169.

Pumphrey RJ (1948): The sense organs of birds. Ibis 90:171-199.

Querubin A, Lee HR, Provis JM, Bumsted O'Brien KM (2009): Photoreceptor and ganglion cell topographies correlate with information convergence and high acuity regions in the adult pigeon (Columba livia) retina. J Comp Neurol 517:711-722.

Rahman ML, Aoyama M, Sugita S (2006): Number, distribution and size of retinal ganglion cells in the jungle crow (Corvus macrorhynchos). Anat Sci Int 86:252-259.

Rattenborg NC, Lima SL, Amlaner CJ (1999): Half-awake to the risk of predation. Nature 397:397-398

Raveling DR, Crews WE, Klimstra WD (1972): Activity patterns of Canada geese during winter. Wilson Bull 84:278-295.

Seddon LM, Nudds TD (1994): The costs of raising nidifugous offspring - brood rearing by giant Canada geese (Branta canadensis maxima). Can J Zool 72:533-540.

Sjöberg G (1994): Factors affecting nest defence in female. Canada geese Branta canadensis. Ibis 136:129-135.

Slonaker JR (1897): A comparative study of the area of acute vision in vertebrates. J Morphol 13:445-494.

Stalmaster MV (1987): The Bald Eagle. New York, Universe Books.

Stone J (1981): The Wholemount Handbook. A Guide to the Preparation and Analysis of Retinal Wholemounts. Sydney, Maitland.

Vincent SB (1912): The mammalian eye. J Anim Behav 2:249-255.

Wathey JC, Pettigrew JD (1989): Quantitative analysis of the retinal ganglion cell layer and optic nerve of the barn owl Tyto alba. Brain Behav Evol 33:279-292.

Wood CA (1917): The Fundus Oculi of Birds: Especially as Viewed by the Ophthalmoscope; a Study in Comparative Anatomy and Physiology. Chicago, Lakeside Press. 